\title{
Inhibition of staphylococci and $S$. aureus in wastewater by ferrates and electrochemical methods
}

\author{
Alžbeta Medved'ová ${ }^{1}$, Stanislava Kecskesová ${ }^{2}$, Anna Krivjanska ${ }^{2}$, Marian Vojs ${ }^{3}$, \\ Marián Marton ${ }^{3}$, Jan Filip ${ }^{4}$, Miroslav Fehér ${ }^{2}$, Tomáš Mackulak ${ }^{2}$ \\ ${ }^{1}$ Department of Nutrition and Food Quality Assessment, Faculty of Chemical and Food Technology, \\ Slovak University of Technology, Radlinského 9, 81237 Bratislava, Slovakia \\ ${ }^{2}$ Institute of Chemical and Environmental Engineering, Faculty of Chemical and Food Technology, \\ Slovak University of Technology, Radlinského 9, 81237 Bratislava, Slovakia \\ ${ }^{3}$ Institute of Electronics and Photonics, Faculty of Electrical Engineering and Information Technology, \\ Slovak University of Technology, Ilkovičova 3, 81219 Bratislava, Slovakia \\ ${ }^{4}$ Regional Centre of Advanced Technologies and Materials, Departments of Physical Chemistry and Experimental \\ Physics, Faculty of Science, Palacký University in Olomouc, Šlechtitelů 27, 78371 Olomouc, Czech Republic \\ tomas.mackulak@stuba.sk
}

\begin{abstract}
Increasing concentration of antibiotics in environment and their subinhibitory concentrations in wastewater may result in increased antibiotic resistance of present bacteria. Therefore, this study was aimed to analyze the efficiency of coagulase-positive staphylococci and Staphylococcus aureus inhibition in wastewater by electrochemical methods and addition of ferrates. Advanced electrochemical oxidation by boron doped diamond electrodes in anode; cathode and anode-cathode connection were used for wastewater disinfection. Results showed that the most effective connection was the anodic one, as complete inhibition of coagulasepositive staphylococci as well as of $S$. aureus was observed after $40 \mathrm{~min}$. Energy consumption was $3.69 \mathrm{kWh} / \mathrm{m}^{3}$ for effluent wastewater disinfection. The second studied method of wastewater disinfection was the application of powdered ferrates. Addition of $100 \mathrm{mg}$ of ferrates resulted in the inhibition of $84-96 \%$ of coagulasepositive staphylococci and 97-99\% of $S$. aureus in influent water, while the inhibition of coagulase-positive staphylococci and $S$. aureus was $61-83 \%$ and $83-86 \%$, respectively, in effluent wastewater.
\end{abstract}

Keywords: BDD electrode, coagulase-positive staphylococci, disinfection, ferrates, municipal wastewater, Staphylococcus aureus

\section{Introduction}

The presence of pharmaceuticals, illicit drugs, hormones or other micropollutants and their metabolites can have negative effect on water animals, plants and microorganisms (Brodin et al., 2013; Le at al., 2014; Mackulak et al., 2015a, 2015b; Nuel et al., 2018; Wilkinson et al., 2018). Besides these micropollutants, the presence of antibiotic resistant bacteria and genes encoding this resistance is monitored in wastewater (Novo et al., 2013; Birošová et al., 2014). Elimination efficiency of bacteria and micropollutants at Wastewater Treatment Plants (WWTPs) is limited and therefore many recent works are focused on the removal of these contaminants (Kümmerer, 2009; Mackulak et al., 2015b; Michael-Kordatou et al., 2018; Nuel et al., 2018).

The presence of pathogenic and potentially pathogenic bacteria is of particular concern. While some bacteria are mainly nosocomial, some are community-acquired, including coagulase-positive staphylococci and Staphylococcus aureus. Staphylococci frequently colonize the nasal vestibule and skin of about $10-50 \%$ of asymptomatic humans (ECDC, 2017). Moreover, pathogenic S. aureus is regarded as a "superbug" due to its huge capacity to be resistant to a wide range of antibiotics, e.g. $S$. aureus strains resistant to methicillin (MRSA) or vancomycin (VISA/VRSA) and to many other antibiotics. These strains represent an urgent global problem since the mortality of $S$. aureus bacteremia remains approximately $20-40 \%$ despite the availability of effective antimicrobials (Mylotte et al., 1987; ECDC, 2017). In community, S. aureus can be easily transferred from carriers or infected persons via direct contact and specific carriers (Stepanović et al., 2008) as it can survive in different environments, including wastewater.

Nowadays, many scientific studies deal with chemical and biological elimination of micropollutants such as X-ray substances, antibiotics, psychoactive pharmaceuticals, drugs and resistant types of microorganisms in municipal wastewater (Golovko et al., 2014; Mackulak et al., 2015a; Verlicchi and Zambello, 2015; Iakovides et al., 2019; Kulandaivelu et al., 2019). Wastewater from point sources, e.g. health care institutions, are intensively studied to find biological and chemical methods for wastewater treatment such as membrane bioreactors, Fenton reaction, ozonization, heteroge- 
neous catalysis, boron-doped diamond electrodes (BDDE), application of ferrates etc. (Verlicchi and Zambello, 2015; Mackulak et al., 2015a, 2015b, 2016; Michael-Kordatou et al., 2018; Kulandaivelu et al., 2019). These techniques show significant degradation of various groups of pharmaceuticals and illegal drugs. These processes produce radicals efficiently eliminating multidrug-resistant microorganisms (Michael-Kordatou et al., 2018; Yuan et al., 2013). Furthermore, it is possible to combine these methods with the original ones. A good example is shown in the study by Kajitvichyanukul and Suntronvipart (2006), where the photoFenton reaction was combined with biological treatment. Application of BDDE is one of the most promising techniques; however, the research is still insufficient. Therefore, this study deals with monitoring of coagulase-positive staphylococci and $S$. aureus in wastewater from Slovak WWTPs and the possibility of using ferrates and boron doped diamond electrodes application as disinfection methods.

\section{Material and methods}

\section{Wastewater sampling}

In this study, wastewater from Petržalka WWTP was used. Samples from influent and effluent of Petržalka WWTP were taken on 14. 9. 2015 and 14. 1. 2016 during 24 hours by an automatic sampler at the entry into the WWTP mechanical stage (Mackulak et al., 2015a, 2015b). WWTP Petržalka treats wastewater from the largest housing estate in Bratislava as well as wastewater from health care facilities with about 2000 hospital beds. The WWTP is designed to treat wastewater from 200000 p.e. (population equivalent) and contains a mechanical pre-treatment stage for raw wastewater and a biological treatment stage, which is designed as RADN (based on the ongoing processes - regeneration, anaerobia, denitrification and nitrification). The produced sludge is digested and produced biogas energy is recovered.

\section{Determination of S. aureus in wastewater}

Presumptive counts of coagulase-positive staphylococci and $S$. aureus were determined after cultivation on Baird-Parker agar (Sigma-Aldrich, St. Louis, USA) according to EN ISO 6888-1 (2003) with $48 \mathrm{~h}$ incubation at $37 \pm 0.5^{\circ} \mathrm{C}$ under aerobic conditions. The suspected colonies of coagulase-positive staphylococci and S. aureus were distinguished based on their typical appearance as it is mentioned in ISO 6888:1 (2003) and were further confirmed by tube coagulase test, microscopic examination, the presence of catalase using a $3 \%$ solution of hydrogen peroxide and by the MALDI-TOF biotyper.
Production and use of $B D D$ electrode for disinfection The used BDD thin films were grown for $120 \mathrm{~min}$ (thickness of about $500 \mathrm{~nm}$ ) in a HFGVD (Hot filament chemical vapor deposition) reactor on both sides of an Si (10 $910 \mathrm{~mm}$ ) substrate. Boron deposition was achieved by adding trimethylboron (TMB) into the $2 \% \mathrm{CH}_{4}$ in $\mathrm{H}_{2}$ gas mixture to obtain the $\mathrm{B} / \mathrm{C}$ ratio of $10000 \mathrm{ppm}$. The deposition pressure was $3 \mathrm{kPa}$ and substrate temperature was $650{ }^{\circ} \mathrm{C}$. Gases were activated by five tungsten filaments (0.7 mm diameter) heated up to $2100{ }^{\circ} \mathrm{C}$. Surface of the BDD thin film was observed by SEM JEOL $7500 \mathrm{~F}$ (Figure 1).

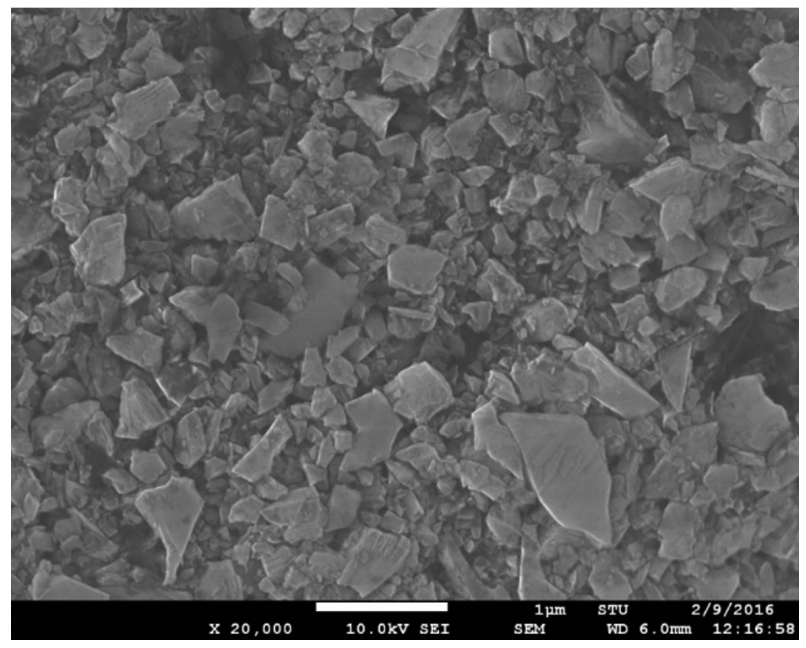

Fig. 1. SEM image of BDD electrode surface.

In Fig. 1, fine polycrystalline diamond surface with sub-micron crystal size can be seen. For testing purposes, a prototype electrode system was prepared consisting of 10 BDD thin film overgrown silicon substrates positioned in two rows by five as the anode $\left(16 \mathrm{~cm}^{2}\right)$ and a graphite rod cathode $(10 \mathrm{~mm}$ diameter) located above $\left(10 \mathrm{~cm}^{2}\right)$ the anode. Stabilized DC power supply GPS 3005 (Goldsun Electronics Co., Ltd., Suzhou City, China) was used for anodic disinfection (Mackulak et al., 2016). Boron-doped diamond electrode connected in three different ways was inserted into $300 \mathrm{ml}$ sample of wastewater. In the first two cases, the BDD electrode was connected as the anode or cathode while the graphite electrode was used as the second electrode. In the third case, the BDD electrode served concurrently as anode and cathode. The distance between electrodes was $1 \mathrm{~cm}$ and DC power supply set to $30 \mathrm{~V}$ was used to create the potential difference. Wastewater disinfection time was 60 min while samples for treatment efficiency analysis were taken at 5 and $60 \mathrm{~min}$. In case of BDD electrode connected as anode, the samples were taken after 2, 5, 10, 20, 40 and $60 \mathrm{~min}$ of disinfection. Temperature of the samples during the 
disinfection was monitored as increased temperature was expected with this type of treatment.

\section{Production and use of Fe (VI) for disinfection}

Potassium ferrate was prepared as follows: electrolysis was performed in an oil thermostat with a calibrated sensor, stainless steel box and PTFE open crucible with the sample $(\mathrm{KOH})$. Reference end of the thermocouple was immersed in a Dewar flask with ice water. Anode was composed of steel class 11 (Valsteel, Zubří, Czech Republic) comprising five interconnected rods with the diameter of $8.5 \mathrm{~mm}$ and length of $46 \mathrm{~mm}$. The counter electrode was composed of the same material as the anode. The cathodic and the anodic compartments were divided by a diaphragm. Mass fraction of $\mathrm{KOH}$ was below $70 \%(\mathrm{w} / \mathrm{w})$. Based on the phase diagram, the temperature for this experiment was chosen to be $40^{\circ} \mathrm{C}$. The working anodic current density was optimized to be $20 \mathrm{~mA} / \mathrm{cm}^{2}$. The final concentration of the prepared potassium ferrate was approximately 80 \% (w/w) (Czölderová et al., 2018).

Three different amounts of ferrates - 10, 50 and $100 \mathrm{mg}$ (obtained from Palacký University in Olomouc, Czech Republic) were added into $300 \mathrm{ml}$ of wastewater samples from influent and effluent of the WWTP. The solution was subsequently intensively mixed for one hour on a shaker at laboratory temperature. $\mathrm{OH}^{-}$ions are released into wastewater during this method of disinfection and thus the $\mathrm{pH}$ change was monitored for the ferrates samples of 10 and $100 \mathrm{mg}$.

\section{Results and discussion}

Two possible types of wastewater disinfection methods: application of boron doped diamond electrode and addition of ferrates, were compared in this study. Efficiency of these methods in reducing the counts of coagulase-positive staphylococci and $S$. aureus was studied in influent and effluent wastewater of WWTP Petržalka, collecting $24 \mathrm{~h}$ wastewater samples on 9. 14. 2015 and 1. 14. 2016. A BDD electrode was used in three different connections, as anode or cathode with a counterpart carbon electrode and concurrently as anode and cathode. Ferrates powder was added in three different doses $-10,50$ and $100 \mathrm{mg}$, to $300 \mathrm{ml}$ of wastewater samples.

The obtained results, summarized in Table 1 and Table 2, showed that the most effective application of the BDD electrode against coagulase-positive staphylococci and $S$. aureus in wastewater was obtained using the anodic connection as the inhibition up to $100 \%$ (decrease about $2 \log \mathrm{CFU} / \mathrm{ml}$ ) was reached. These results correspond well with those of other studies where the anodic connection was marked as a method with the highest efficiency (Panizza and Cerisalo, 2009; Rajab et al., 2015). The highest efficiency of anodic connection can be explained by the production of hydroxide radicals $\mathrm{HO}^{\circ}$, which belong to the strongest oxidizing agents (Kraft, 2008; Michael-Kordatou et al., 2018). In case of cathodic connection, hydrogen peroxide $\left(\mathrm{H}_{2} \mathrm{O}_{2}\right)$ is generated as the reactive agent (Kraft, 2008). However, as staphylococci are catalase-positive (Halpin-Dohnalek and Marth, 1989), they can degrade a certain amount of $\mathrm{H}_{2} \mathrm{O}_{2}$ to water and free oxygen by enzyme catalase. Therefore, the cathodic connection has lower efficiency compared to the anodic one. Surprisingly, the lowest inhibitory efficiency was observed using the BDD in simultaneous anode-cathode connection.

Tab. 1. Efficiency of coagulase-positive staphylococci and S. aureus inhibition in wastewater samples from 9. 14. 2015.

\begin{tabular}{|c|c|c|c|c|c|}
\hline \multirow{2}{*}{ Disinfection method } & \multirow{2}{*}{$\begin{array}{l}\text { Disinfection } \\
\text { application }\end{array}$} & \multicolumn{2}{|c|}{$\begin{array}{l}\text { Inhibition efficiency [\%] } \\
\text { INFLUENT water }\end{array}$} & \multicolumn{2}{|c|}{$\begin{array}{c}\text { Inhibition efficiency [\%] } \\
\text { EFFLUENT water }\end{array}$} \\
\hline & & $\begin{array}{l}\text { coagulase-positive } \\
\text { staphylococci }\end{array}$ & S. aureus & $\begin{array}{l}\text { coagulase-positive } \\
\text { staphylococci }\end{array}$ & S. aureus \\
\hline BDD electrode & $5 \mathrm{~min}$ & 83.0 & 96.8 & 56.5 & 100.0 \\
\hline Anode & $60 \mathrm{~min}$ & 100.0 & 100.0 & 100.0 & 100.0 \\
\hline BDD electrode & $5 \min$ & 74.8 & 94.8 & 21.7 & 42.9 \\
\hline Cathode & $60 \mathrm{~min}$ & 100.0 & 100.0 & 69.6 & 85.7 \\
\hline BDD electrode & $5 \min$ & 54.1 & 90.7 & $*$ & $*$ \\
\hline Anode + cathode & $60 \mathrm{~min}$ & 96.1 & 92.3 & 30.4 & 85.7 \\
\hline \multirow{3}{*}{ Ferrates } & $10 \mathrm{mg}$ & 74.0 & 94.3 & $*$ & $*$ \\
\hline & $50 \mathrm{mg}$ & 80.6 & 96.2 & $*$ & * \\
\hline & $100 \mathrm{mg}$ & 84.3 & 97.5 & 82.6 & 85.7 \\
\hline
\end{tabular}

*increase in bacteria number 
Tab. 2. Efficiency of coagulase-positive staphylococci and S. aureus inhibition in wastewater samples from 1. 14.2016.

\begin{tabular}{|c|c|c|c|c|c|}
\hline \multirow{2}{*}{$\begin{array}{l}\text { Disinfection } \\
\text { method }\end{array}$} & \multirow{2}{*}{$\begin{array}{l}\text { Disinfection } \\
\text { application }\end{array}$} & \multicolumn{2}{|c|}{$\begin{array}{l}\text { Inhibition efficiency [\%] } \\
\text { INFLUENT water }\end{array}$} & \multicolumn{2}{|c|}{$\begin{array}{c}\text { Inhibition efficiency [\%] } \\
\text { EFFLUENT water }\end{array}$} \\
\hline & & $\begin{array}{l}\text { coagulase-positive } \\
\text { staphylococci }\end{array}$ & S. aureus & $\begin{array}{l}\text { coagulase-positive } \\
\text { staphylococci }\end{array}$ & S. aureus \\
\hline BDD electrode & $5 \mathrm{~min}$ & 73.2 & 93.8 & 17.8 & 50.0 \\
\hline Anode & $60 \mathrm{~min}$ & 99.9 & 99.7 & 100.0 & 100.0 \\
\hline BDD electrode & $5 \mathrm{~min}$ & 74.3 & 93.6 & 16.8 & 75.0 \\
\hline Cathode & $60 \mathrm{~min}$ & 97.4 & 99.4 & 71.0 & 58.3 \\
\hline BDD electrode & $5 \mathrm{~min}$ & 65.2 & 86.7 & $*$ & $*$ \\
\hline Anode + cathode & $60 \mathrm{~min}$ & 81.2 & 92.9 & 16.8 & 33.3 \\
\hline \multirow{3}{*}{ Ferrates } & $10 \mathrm{mg}$ & 50.9 & 95.9 & $*$ & $*$ \\
\hline & $50 \mathrm{mg}$ & 66.4 & 95.1 & $*$ & $*$ \\
\hline & $100 \mathrm{mg}$ & 96.3 & 98.8 & 60.8 & 83.3 \\
\hline
\end{tabular}

*increase in bacteria number

The addition of ferrates led to the inhibition of both coagulase-positive staphylococci and S. aureus in influent wastewater in all cases. Moreover, the higher the addition of ferrates, the more intensive staphylococci inhibition, ranging from $74 \%$ to $97.5 \%$ in the September sample and from $50.9 \%$ to $98.8 \%$ in the January sample.

On the other hand, the increase of coagulasepositive staphylococci including $S$. aureus counts in effluent samples was observed in case of 10 and $50 \mathrm{mg}$ ferrates addition. The addition of $10 \mathrm{mg}$ of ferrates led to an average increase of about $1.47 \pm 0.15 \log \mathrm{CFU} / \mathrm{ml}$ of studied bacteria, while the addition of $50 \mathrm{mg}$ of ferrates led to the average increase of about $0.61 \pm 0.21 \mathrm{log} \mathrm{CFU} / \mathrm{ml}$. Only the highest ferrates addition caused staphylococci inhibition of about $61-86 \%$.

It is important to remark that added ferrates do not react only with organic substances but also cause water decomposition (see Eq. 1), and the released $\mathrm{OH}^{-}$increases wastewater $\mathrm{pH}$ (Fig. 2), mainly in case of addition of $100 \mathrm{mg}$ of ferrates. The initial wastewater $\mathrm{pH}$ was 7.5 and after ferrates addition it increased to $\mathrm{pH} 9.27$ and 9.55 in influent and effluent water, respectively. Such high $\mathrm{pH}$ values may show inhibition effect on staphylococci as they optimal growth is observed in the $\mathrm{pH}$ range of 6-7 (Halpin-Dohnalek and Marth, 1989).

$$
4 \mathrm{FeO}_{4}^{2-}+10 \mathrm{H}_{2} \mathrm{O} \rightarrow 4 \mathrm{Fe}^{3+}+10 \mathrm{OH}^{-}+3 \mathrm{O}_{2}
$$

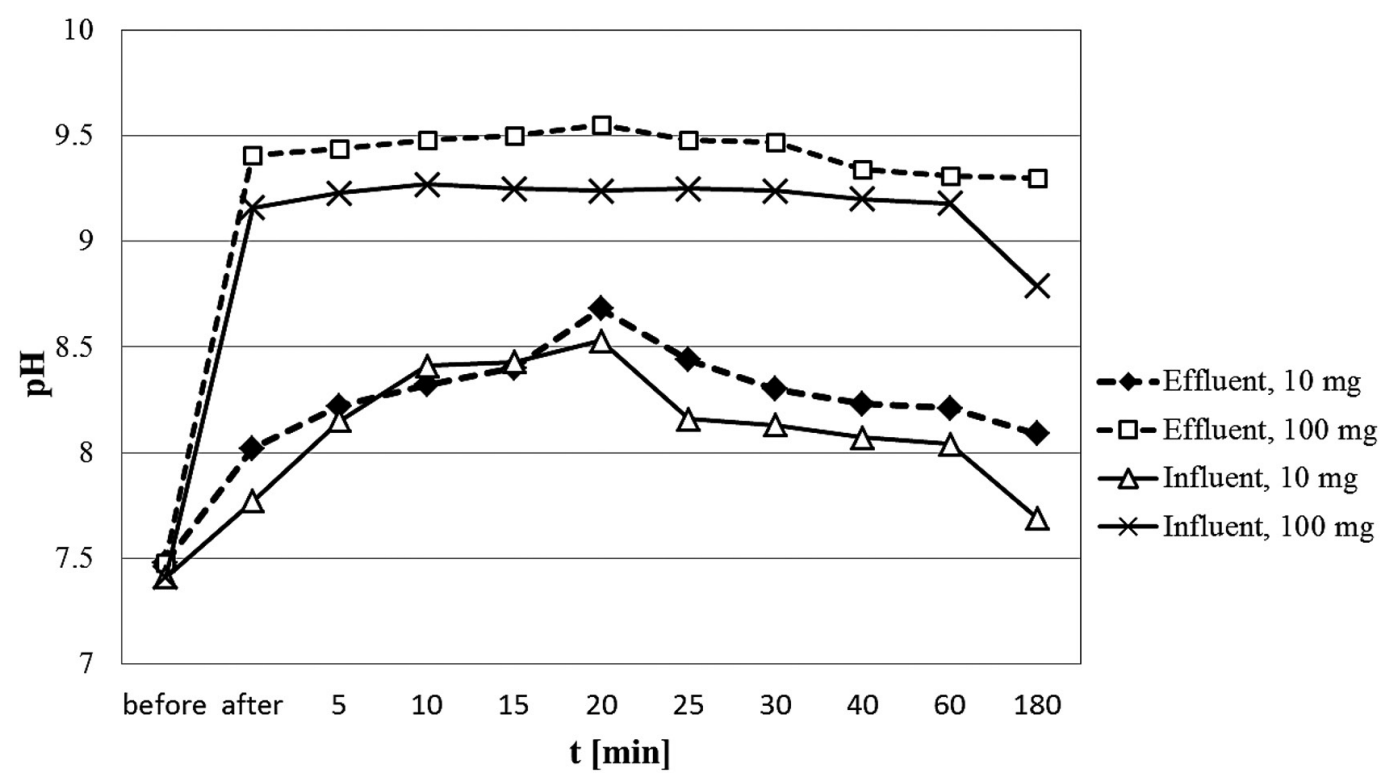

Fig. 2. Changes of pH after adding 10 and $100 \mathrm{mg}$ of powdered ferrates into $300 \mathrm{ml}$ of influent and effluent wastewater. 
These results suggest the following question to be further investigated: Is the disinfecting effect of ferrates due to their oxidizing properties or the high $\mathrm{pH}$ of the sample?

Considering the obtained results it can be concluded that the most effective disinfection method against coagulase-positive staphylococci is the application of BDD electrode in anode connection. However, it is necessary to determine the WWTP stage where it is useful to place the electrodes. Therefore, disinfection efficiency was monitored in dependence on time as it is shown in Fig. 3. In influent wastewater, the coagulase-positive staphylococci were not eliminated even after $60 \mathrm{~min}$ of disinfection (their final count was $2.44 \log \mathrm{CFU} / \mathrm{ml}$ ). However, in effluent wastewater, complete inhibition of staphylococci was observed after $40 \mathrm{~min}$. So, it can be stated that the rate of coagulase-positive staphylococci elimination in early minutes is significantly higher in influent than in effluent water. For example, after $10 \mathrm{~min}$ of disinfection, inhibition efficiency of $70.4 \%$ was observed for staphylococci in influent but it was only $16.8 \%$ in effluent wastewater, suggesting that the rate of disinfection depends on the concentration of bacteria in the sample as the initial staphylococci counts were $4.17 \log \mathrm{CFU} / \mathrm{ml}$ and $1.03 \log \mathrm{CFU} / \mathrm{ml}$ in influent and effluent wastewater, respectively.

Another important information for practical application of the BDD electrode is the energy consumption estimated using Eq. 2 (Rajab et al., 2015).

$$
E\left(\frac{\mathrm{kWh}}{\mathrm{m}^{3}}\right)=\frac{U I T}{V_{v z}}
$$

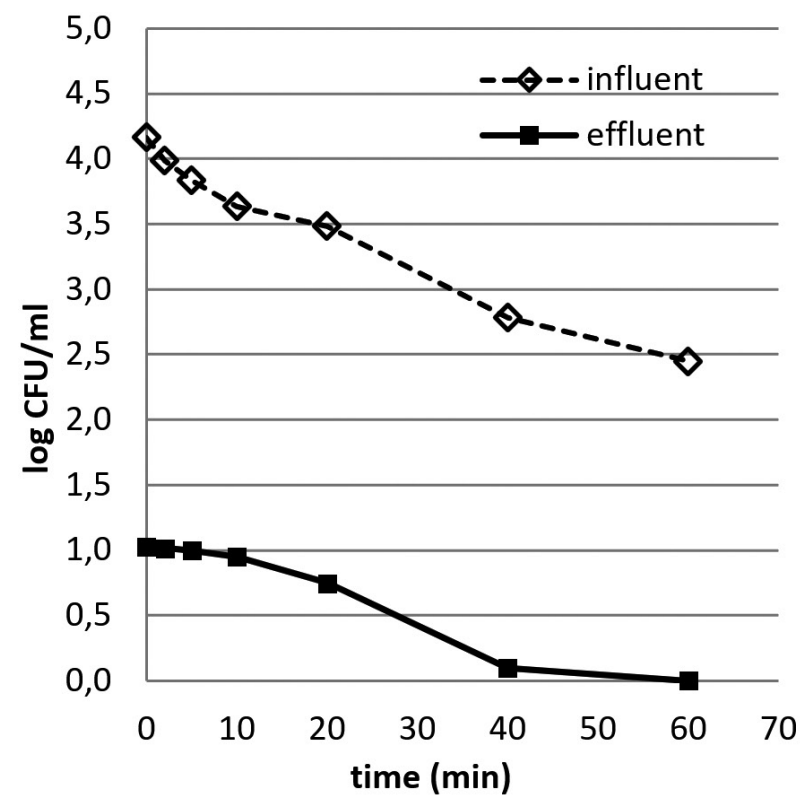

a) where $U$ is the electrical voltage $(\mathrm{V}), I$ the electrical current (A), $T$ time (h) and $V_{v z}$ is the sample volume $\left(\mathrm{m}^{3}\right)$. The initial concentration of coagulase-positive staphylococci in effluent wastewater sample was $1.03 \log \mathrm{CFU} / \mathrm{ml}$. Complete disinfection was reached after $40 \mathrm{~min}$ at $29.7 \mathrm{~V}$ and $60 \mathrm{~mA}$, i.e. energy consumption was $3.96 \mathrm{kWh}$ for complete disinfection of $1 \mathrm{~m}^{3}$ of the effluent sample. Usual energy consumption in a WWTP is about $0.4 \mathrm{kWh} / \mathrm{m}^{3}$; hence, the energy consumption of treatment using the BDD electrode is approximately ten times higher than that of the standard biological method.

\section{Conclusions}

Results of staphylococci inhibition by BDD electrode in three different connections showed that the anodic connection with a graphite electrode counterpart is the most effective one. Using this type of connection, the efficiency of coagulasepositive staphylococci and $S$. aureus elimination reached $100 \%$ (decrease of about $2 \log \mathrm{CFU} / \mathrm{ml}$ ). Considering the disinfection process efficiency, the recommended location of the BDD electrode is the tertiary treatment in the WWTP. A disadvantage of this process is the relatively high energy consumption $\left(3.96 \mathrm{kWh} / \mathrm{m}^{3}\right)$ required to complete coagulase-positive staphylococci elimination. The addition of ferrates as a disinfection method showed the addition of $100 \mathrm{mg}$ of powdered ferrates to be the most efficient. Using lower doses of ferrates (10 and $50 \mathrm{mg}$ ) resulted in an increase of contaminants concentration. Further research on ferrates

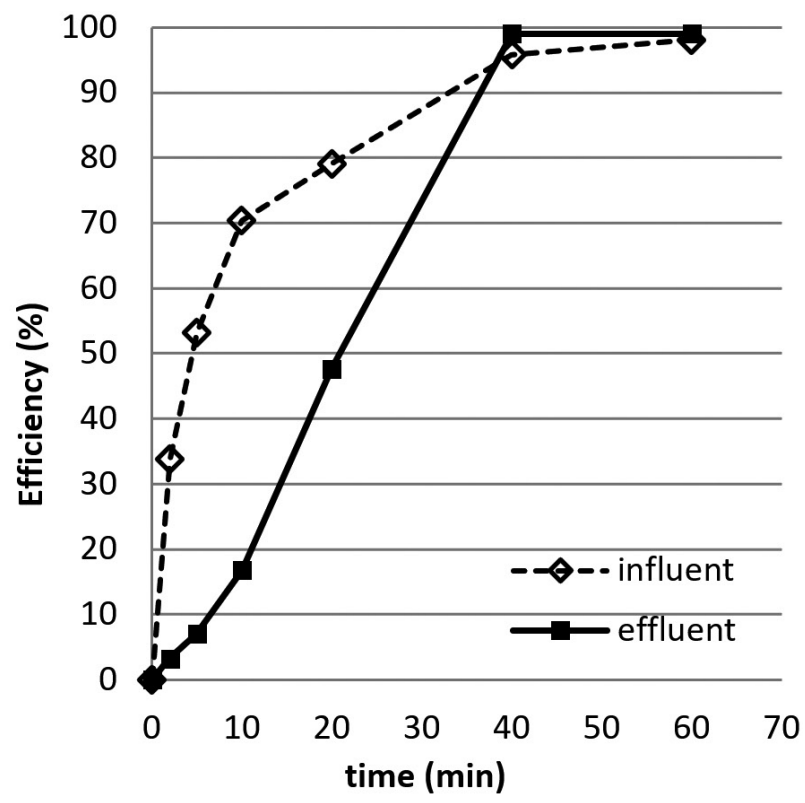

b)

Fig. 3. Time dependence of disinfection efficiency against coagulase-positive staphylococci in influent and effluent wastewater using BDD electrode in anodic connection. 
application is necessary because it is not clear whether the disinfecting effect of ferrates is due to their oxidizing properties or their ability to increase $\mathrm{pH}$ (up to 9.5). Further research on advanced oxidation processes is also needed for intensification of methods to remove micropollutants and resistant types of bacteria from wastewater because these substances can cause health problems.

\section{Acknowledgement}

This work was supported by the Slovak Research and Development Agency under the contract APVV-19-0250, APVV-16-0124, APVV-16-0171, APVV-17-0183. PP-COVID-20-0019 and project VIR-SCAN - Wastewater monitoring data as an early warning tool to alert COVID-19 in the population.

The publication was created as part of a grant scheme project to support young researchers „Domácnosti ako potenciálny zdroj mikrovlákien pre životné prostredie“, v podmienkach STU v Bratislave, „Zdravotnicke zariadenia a hudobné festivaly ako bodové zdroje mikropolutantov v povrchových vodách a možnosti ich účinného odstraňovania“, as well as within the project of a grant scheme to support excellent teams of young researchers in the conditions of $S T U$ in Bratislava „Monitoring a odstraňovanie fragmentov $R N A$ vírusu SARS-CoV-2 v odpadových vodách pomocou železanov",

\section{References}

Baird MR, Lee WH (1995) Int J Food Microbiol 26: 15-24.

Birošová L, Mackulak T, Bodík I, Ryba J, Škubák J, Grabic R (2014) Sci Total Environ 490: 440-444.

Brodin T, Fick J, Jonsson M, Klaminder J (2013) Science 339: 814-815.

Czölderová M, Behúl M, Filip J, Zajíček P, Grabic R, Vojs-Staňová A, Gál M, Kerekeš K, Híveš J, Ryba J, Rybanská M, Brandeburová P, Mackulak T (2018) Chem Eng J 349: 269-275.

ECDC (2017) Antimicrobial resistance surveillance in Europe 2015, Surveillance report, Available in May 2017: http://ecdc.europa.eu/en/publications/ Publications/antimicrobial-resistance-europe-2015.

EN ISO 6888-1 (2003) Microbiology of food and animal feeding stuffs - Horizontal method for the enumeration of coagulase-positive staphylococci (Staphylococcus aureus and other species) - Part 1: Technique using Baird-Parker agar medium, 1-11.
Golovko O, Kumar V, Fedorova G, Randák T, Grabic R (2014) Environ. Sci Pollut Res 21: 7578-7585.

Halpin-Dohnalek MI, Marth EH (1989) J Food Prot 52: 267-282.

Iakovides IC, Michael-Kordatou I, Moreira NFF, Ribeiro AR, Fernandes T, Pereira MFR, Nunes OC, Manaia CM, Silva AMT, Fatta-Kassinos D (2019) Wat Res 159: 333-347.

Kajitvichyanukul P, Suntronvipart N (2006) J Hazard Mater 2: 384-391.

Kraft A (2008) Platinum Met Rev 52: 177-185.

Kulandaivelu J, Gao J, Song Y, Shrestha S, Li X, Li J , Doederer K, Keller J, Yuan Z, Mueller JF, Jiang G (2019) Environ Sci Technol 53: 6245-6254.

Kümmerer K (2009) Chemosphere 75: 435-441.

Li Y, Zhu G, Ng JW, Tan KS (2014) Sci Total Environ 468 : 908-932.

Mackulak T, Mosný M, Grabic R, Golovko O, Koba O, Birošová L (2015a) Environ Toxicol Pharmacol 39: 483-488.

Mackulak T, Mosný M, Škubák J, Grabic R, Birošová L (2015b) Environ Toxicol Pharmacol 39: 969-973.

Mackulak T, Vojs M, Grabic R, Golovko O, Vojs Staňová A, Birošová L, Medvedová A, Híveš J, Gál M, Kromka A, Hanusova A (2016) Monatsh Chem 147: 97-103.

Michael-Kordatou I, Karaolia P, Fatta-Kassinos D (2018) Water Res 129: 208-230.

Mylotte JM, McDemott C, Spooner JA (1987) Reviews of Infectious Diseases 9: 891-907.

Novo A, André S, Viana P, Nunes OC, Manaia CM (2013) Water Res 47: 1875-1887.

Nuel M, Laurent J, Bois P, Heintz D, Wanko A (2018) Sci Total Environ 615: 1099-1109.

Panizza M, Cerisola G (2009) Chem Rev 109: 6541-6569.

Rajab M, Heim C, Letyel T, Drewes JE, Helmreich B (2015) Chemosphere 121: 47-53.

Stepanović S, Ćirković I, Djukić S, Vuković D, ŠvabićVlahović M (2008) Letters in Applied Microbiology 47: 339-341.

Verlicchi P, Zambello E (2015) Sci Total Environ 538: $750-757$.

Wilkinson LJ, Hooda SP, Swinden J, Barker J, Barton S (2018) Environ Pollut 234: 864-875.

Yuan S, Jiang X, Xia X, Zhang H, Zheng S (2013) Chemosphere 90: 2520-2525. 